\title{
Increasing forest loss worldwide from invasive pests requires new trade regulations
}

\author{
Bitty A Roy ${ }^{1 *}$, Helen M Alexander ${ }^{2}$, Jennifer Davidson ${ }^{3}$, Faith T Campbell ${ }^{4}$, Jeremy J Burdon ${ }^{5}$, \\ Richard Sniezko ${ }^{6}$, and Clive Brasier ${ }^{7}$
}

Loss of forests due to non-native invasive pests (including insects, nematodes, and pathogens) is a global phenomenon with profound population, community, ecosystem, and economic impacts. We review the magnitude of pest-associated forest loss worldwide and discuss the major ecological and evolutionary causes and consequences of these invasions. After compiling and analyzing a dataset of pest invasions from 21 countries, we show that the number of forest pest invasions recorded for a given country has a significant positive relationship with trade (as indicated by gross domestic product) and is not associated with the amount of forested land within that country. We recommend revisions to existing international protocols for preventing pest entry and proliferation, including prohibiting shipments of non-essential plants and plant products unless quarantined. Because invasions often originate from taxa that are scientifically described only after their introduction, current phytosanitary regulations - which target specific, already named organisms - are ineffective.

Front Ecol Environ 2014; 12(8): 457-465, doi:10.1890/130240 (published online 15 Sep 2014)

$\mathrm{F}$ orests are being lost or substantially altered worldwide as a result of damage by introduced pests (primarily insects, nematodes, and pathogens). Forest losses due to pests have particular ecological importance because trees dominate about one-third of terrestrial habitats and account for almost three-quarters of the Earth's leaf surface area (Perry et al. 2008). Given that trees are relatively large and long-lived, the loss of even a single species can have a major impact on forest structure and dependent species. In addition to providing economically valuable timber, forests perform many ecosystem services - including regulation of climate and water supply, ero-

\section{In a nutshell:}

- Introductions of non-native invasive pests are dramatically altering forest ecosystems around the world

- The most vulnerable forests are those that feature similar species compositions (eg the temperate forests of Europe, Asia, and the northeastern US)

- Unless effectively restricted, forest pest introductions are projected to increase in number and frequency through two major pathways: importation of wood products and (particularly) importation of live plant materials

- Instead of emphasizing post-invasion responses, worldwide phytosanitary regulations should adopt more proactive approaches to counter pest invasions

${ }^{1}$ Institute for Ecology and Evolution, University of Oregon, Eugene, OR* (bit@uoregon.edu); ${ }^{2}$ Department of Ecology and Evolutionary Biology, University of Kansas, Lawrence, KS; ${ }^{3}$ Biology Department, Bowdoin College, Brunswick, ME; ${ }^{4}$ Forest Health Protection Program, The Nature Conservancy, Arlington, VA; ${ }^{5}$ CSIRO Plant Industry, Black Mountain, Australia; ${ }^{6}$ Dorena Genetic Center, Cottage Grove, OR; ${ }^{7}$ Forest Research, Alice Holt Lodge, Farnham, UK sion control, nutrient cycling, carbon storage, and habitat provision - estimated at US\$4.7 trillion per year in 1997 (Costanza et al. 1997).

The news media occasionally highlight specific instances of forest loss as a consequence of introduced pests, including the enormously destructive emerald ash borer (Agrilus planipennis) in the US. What is less frequently recognized is that many damaging invasions of pathogens and insects (and the associated forest losses) are continuing unabated across the globe. Currently, millions of ash (Fraxinus spp) trees, keystone and common species in the UK and the rest of Europe, are dying due to the introduction of Hymenoscyphus pseudoalbidus (formerly Chalara fraxinea) dieback fungus (Pautasso et al. 2013); an introduced rust pathogen in Australia threatens the continent's Eucalyptus spp and related members of the Myrtaceae (Carnegie and Cooper 2011); and whitebark pine (Pinus albicaulis) has recently been designated as endangered in Alberta, Canada, because of the impact of a non-native pathogen (Cronartium ribicola), and may become similarly listed in the US (Keane et al. 2012). Furthermore, new fungal pathogens are emerging as a result of hybridization between introduced and native pathogens (Brasier 2000), with the rate of fungal invasions recently reported to be increasing rapidly (Fisher et al. 2012). Although likely underestimated, the recorded number of non-native forest pests (in countries for which data are available; Figure 1) highlights the extent of nonnative introductions; there are serious implications for future forest health if even just a small percentage of these organisms progress from establishment and naturalization to causing epidemics (Figure 2). In the UK alone, new outbreaks of non-native forest pests are presently occurring at a rate of around one per year; since 2009, chestnut blight (caused primarily by the pathogenic fun- 


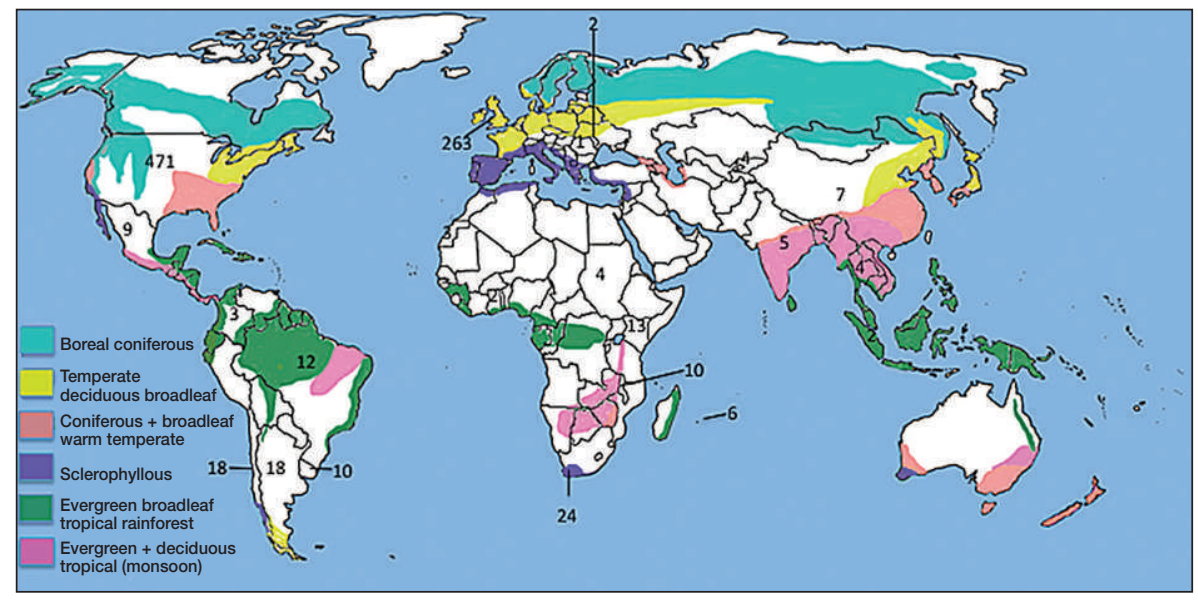

Figure 1. The major forest biomes (approximately located) and the number of non-native forest pests (pathogens and herbivores) as reported from a diversity of countries. Countries without a number indicate a lack of data for that country. Data sources: US = Aukema et al. (2010); developing nations = FAO (2009a); UK = Natural England non-native audit (www.naturalengland.org.uk/ourwork/conservation/biodiversity/threats/nonnativeaudit.aspx). The forest biome map was based on: www.daviddarling.info/encyclopedia/F/AE_forests.html.

Liebhold et al. 2012). Thus, there is greater risk of pest invasions occurring in countries with higher levels of such imports (eg the US and Europe [Liebhold et al. 2012; Santini et al. 2013] and, increasingly, China). Indeed, we found that the number of forest pests per country correlates with gross domestic product (GDP; Figure 3a) but not with forested land area (Figure $3 b$ ). An alternative explanation for the association of pests and GDP is that similar incursions are occurring in many areas of the world, but developing countries have fewer resources for detecting and reporting new pests. However, in countries where more resources are devoted to pest tracking, a greater proportion of new pests are

gus Cryphonectria parasitica), Phytophthora lateralis, Phytophthora austrocedrae, a new evolutionary lineage of Phytophthora ramorum, Chalara ash dieback, elm yellows, and Asian long-horned beetles (Anoplophora glabripennis) have been recorded and subject to control efforts.

Different countries and forest types likely have different vulnerabilities to invasive pests as a result of varying economic, ecological, and evolutionary factors (Table 1). We review the influence of these factors on invasions within the context of the two common pathways of introduction for forest pests: in imported wood products and living plant materials. We then briefly discuss the consequences for world forests, and conclude with a set of policy recommendations that if enacted would drastically limit new invasions.

\section{Economic factors influencing invasions}

Invasions of non-native forest pests primarily occur as a consequence of international trade. Pests arrive with plants that are being imported for nurseries and plantations, in raw log imports, in shipping pallets, and in other wood products (Brasier 2008; Aukema et al. 2010; likely to be reported and more resources would probably be dedicated to reducing the frequency of pest incursions.

Once relatively protected due to reduced exposure, economically emerging countries such as China are now experiencing major pest invasions (Xu et al. 2006) and are also likely to be exporting more goods and associated pests. Given the expected time lag between the arrival of an invasive species and populations becoming large enough to cause observable damage (Dietz and Edwards 2006), we predict that China's pest numbers will reflect its 1990s economic upturn within the next two decades. Furthermore, if more data were available from developed countries such as Japan, Australia, and Canada, we predict that two lines could be fitted to Figure 3a: one for developed nations and another for developing nations. These lines would likely be parallel, but the developed nations' line will be higher due to (1) pest accumulation over a longer time period and (2) increased detection. Overall, we anticipate a continuing rise in forest pest introductions in all countries, including developing nations.

A recent case of an invasive forest pest originating from wood products is the redbay ambrosia beetle (Xyleborus glabratus) and its associated wilt-causing fungus (Raffaelea

\begin{tabular}{lll}
\hline \multicolumn{2}{l}{ Table 1. Economic, ecological, and evolutionary factors important in pest invasions } \\
\hline Economic & \multicolumn{1}{c}{ Ecological } & \multicolumn{1}{c}{ Evolutionary } \\
\hline - Trade & - Frequency of introductions & - Lack of coevolutionary history \\
- Trees for plantations & - Presence of a host & - Infectivity and aggressiveness \\
- Wood products & - Population size & - Resistance and tolerance \\
- Trees for nurseries & - Biodiversity & - Life histories of pests and hosts \\
- Tourism & - Biotic resistance & - Host range \\
- Detection and interception & - Enemy release & - Mating system of the pests \\
& - Climate & - Phylogenetic relatedness of the hosts \\
& & - Rapid pest evolution in new range \\
& & - Natural selection \\
\hline
\end{tabular}



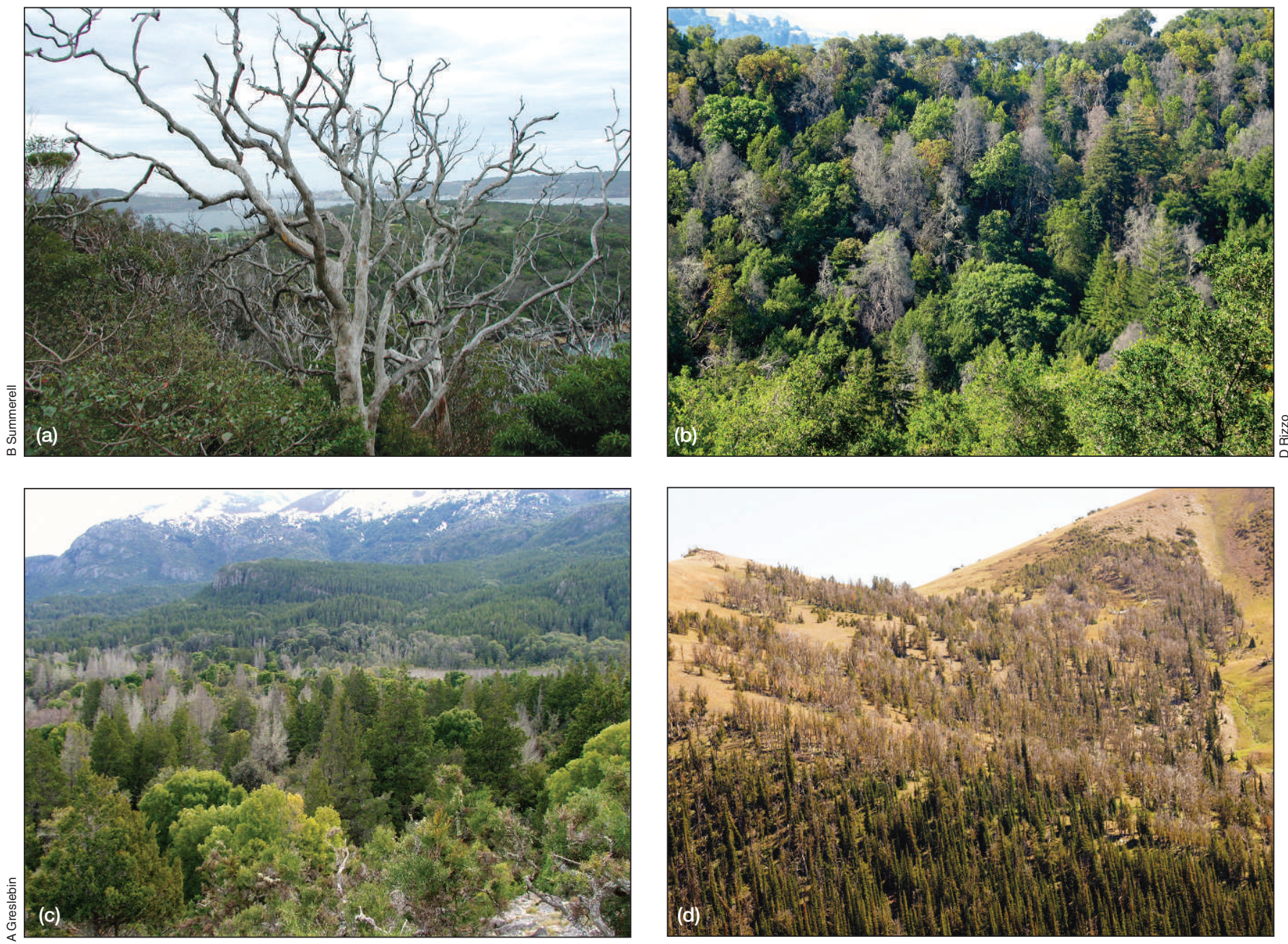

Figure 2. Examples of dieback from different forest types around the world. (a) Eucalyptus (Eucalyptus spp) killed by jarrah dieback (Phytophthora cinnamomi) in Australia. (b) Oaks and tan oaks (Quercus spp and Notholithocarpus, respectively) killed by sudden oak death (Phytophthora ramorum) in California. (c) Ciprés de la cordillera (Austrocedrus chilensis) killed by Phytophthora austrocedrae in Argentina. (d) Whitebark pine forest (Pinus albicaulis) killed by non-native white pine blister rust (Cronartium ribicola) in the Wallowa Mountains of Oregon.

lauricola), which were probably originally introduced into the US via wood packing materials from Asia (Mayfield and Thomas 2009). This insect-fungus association is presently attacking a wide range of native and managed hosts in the laurel family (Lauraceae) in the southeastern US, including avocado (Persea americana) plantations, where the losses could reach as high as US $\$ 356$ million (Evans et al. 2010). The speed of native forest loss has been notable; in less than 1.5 years, mortality in native redbay trees (Persea borbonia) alone was 70\% (Fraedrich et al. 2008). At least 14 other woody native members of the Lauraceae in the southern US and California, including some that are used as urban shade trees, are likely to suffer mortality as these pests spread (Peña et al. 2012).

Pathogens in particular are often initially introduced into plantations via asymptomatic living plant materials, including seedlings, buds, cuttings, and seeds (Denman et al. 2008; Andjic et al. 2011; Liebhold et al. 2012; Sakalidis et al. 2013). Prior to the 1950s, regulation of the humanmediated international transport of plants was negligible, and plant materials were routinely moved between continents (Burgess and Wingfield 2001). The prolonged travel times by cargo ships likely prevented the transfer of some but not all latent pathogens. For example, white pine blister rust - a disease caused by the fungal pathogen C ribicola, which is currently decimating populations of eight (of nine total) five-needled pine species in North America (Schoettle et al. 2011) - was accidentally introduced on white pine (Pinus strobus) seedlings from Europe around 1910 (Keane et al. 2012).

International plant health regulation is currently operated via the Sanitary and Phytosanitary Agreement of the World Trade Organization (WTO). However, these rules have been largely ineffective at protecting forests and other ecosystems (natural or managed) for two main reasons: (1) their primary aim is to promote international trade rather than to protect the environment and (2) associated legislation requires a named organism to be identified as a pest, even though invading organisms are often either "new" (ie scientifically unrecognized and, as 

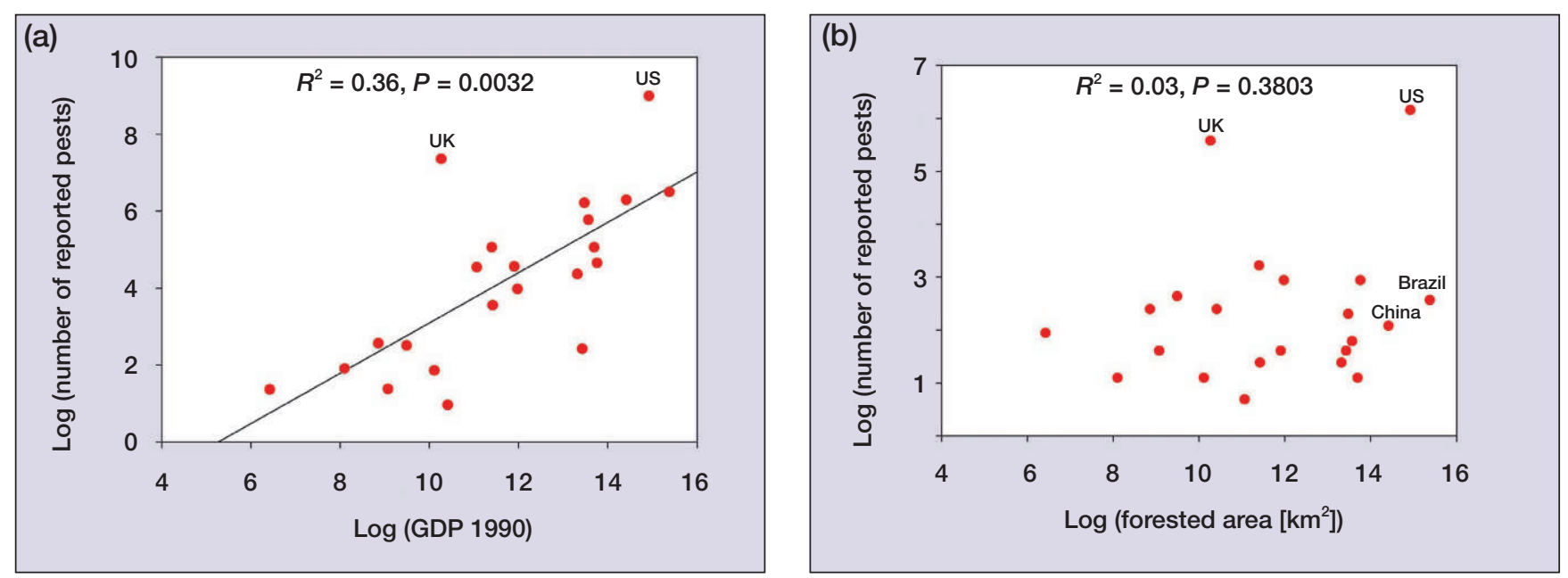

Figure 3. Explanatory regressions for world non-native forest pests. (a) Gross domestic product (GDP, in billions \$US) in 1990 versus the number of pests reported from each country (see Figure 1). We used GDP from more than 20 years ago to account for the lag between introduction and population expansion (Dietz and Edwards 2006). (b) Forested area versus the number of pests reported from each country. To meet the assumptions of regression, we log-transformed all of the variables for analysis. Historical GDP data constructed with data from the following sources: World Bank World Development Indicators (http://data.worldbank.org/data-catalog/world-development-indicators) and historical information from International Financial Statistics of the International Monetary Fund (www.imf.org/external/data.htm). Forest area data are from the UN Food and Agriculture Organization (FAO 2009b).

such, "nameless") species or not troublesome within their native ranges (Wingfield et al. 2001; Brasier 2008). Dothistroma needle blight (causal fungus Dothistroma pini) and Sirex noctilio wood wasps, for instance, were not problematic until after their accidental displacement from their forests of origin (Burgess and Wingfield 2001). Furthermore, many currently highly damaging forest pathogens, such as those associated with ash dieback and sudden oak death, were effectively unknown to science and were therefore not detected and stopped at border checkpoints.

Population genetic data typically implicate large-scale movement of live material in spreading these organisms (Andjic et al. 2011; Goss et al. 2011). For example, genetic data indicate that around the world, non-native pathogens that damage eucalyptus trees are moving from plantations into native forests with species in the same family as eucalyptus, the Myrtaceae (Pérez et al. 2008, 2013; Sakalidis et al. 2013). The scale of this movement, and the potential for problems in native forests as a result, is high because eucalyptus species are so widely planted. For example, Brazil has about 4.8 million ha of planted non-native eucalyptus (ABRAF 2011) and forests full of related species in the family Myrtaceae, which is the most common family of native forest trees in that country (Oliveira and Fontes 2000).

Horticultural nurseries also import and export live plant materials, which often lead to pathogen introductions. Three recent cases make this clear. P ramorum, a pathogen of probable Asian origin that has an enormous array of potential hosts in its introduced range (Kluza et al. 2007), was responsible for killing millions of native oaks (Quercus spp) and tanoaks (Notholithocarpus densiflorus) in California during the 1990s (Figure 2b; Rizzo et al. 2002), and plantation larches (Larix spp) in the UK since 2009 (Brasier and Webber 2010). Initially, P ramorum spread rapidly within the nursery trade in both North America and Europe and then expanded from nurseries into forests (Goss et al. 2011). Unfortunately, the potential international range of $P$ ramorum is vast, encompassing most broad-leaved forests in the world (Kluza et al. 2007). Another example of an apparently nursery-trade-transported pathogen is guava rust (Puccinia psidii complex), which was first reported in 2010 in Australia on a native tree in the same family as guava (Myrtaceae) growing in a commercial nursery (Carnegie and Cooper 2011). Now, many nurseries throughout Australia carry infected host species (Carnegie and Cooper 2011) and the pathogen has since spread from nurseries into native forests. Currently, it occurs on about 120 native and non-native Myrtaceae species and has spread over $1200 \mathrm{~km}$ along the Australian coast (www.invasives.org.au). Because guava rust infects many Myrtaceae species in its native South America and most Australian native species tested to date are susceptible (Zauza et al. 2010), it is likely to spread to many of the 70 native genera and 1400 species of Myrtaceae in Australia (NSW flora online http://plantnet.rbgsyd.nsw.gov.au). Finally, the appearance of large numbers of forest pathogens in Europe in recent years has been strongly linked to ornamental imports and unrestricted movement of living plants within the European Union (EU; Santini et al. 2013).

\section{Factors influencing invasiveness}

Several ecological factors - including the number of introductions, the physical environment, and character- 
istics of both the hosts and pests - may facilitate invasions (Table 1).

Is the number of pests introduced correlated with forest damage and loss? The most important ecological factors predicting forest pest invasion are (1) the frequency of introductions, as this reflects the probability that sufficient individuals will be introduced to start a founding population; (2) that a strain with broad host tolerance is introduced; or (3) that the pest encounters host populations under stress due to drought or other climatic stressors (Haack 2006). Interdiction records at commercial ports of entry suggest that not all pests arriving in a new area succeed in invading and establishing populations outside of their native ranges; however, a higher number of introductions enhances the probability that a subset thereof will successfully become established (Haack 2006; Aukema et al. 2011). In addition, the more kinds of pests a plant has on it, the more likely survival or reproduction will be reduced (Roy et al. 2011).

Does the diversity of tree species play a protective role? It has been hypothesized that species-rich forests should have fewer pests because effective host density is lower (Mitchell et al. 2002) and because of interference: propagules can be "lost" by landing on non-hosts (Burdon and Chilvers 1982). While greater diversity may aid in reducing pathogen spread in grasslands (Mitchell et al. 2002), there is less supporting evidence for this mechanism in forests. Meta-analyses have shown that, in a forest, the presence of particular host tree species is more important than biodiversity per se (Vehvilainen et al. 2007). Simply put, some tree species are more vulnerable (ie less resistant) than others. Furthermore, the effectiveness of biodiversity in protecting a forest is somewhat idiosyncratic, depending on factors such as the time of year, the pest species involved, and host density (Vehvilainen et al. 2007).

Evolution - both historical and current - plays a central role in pest invasions. A defining feature of nonnative pests is that they have not coevolved with the forests into which they have been introduced. Yet evolutionary history determines the host range plasticity of the pests, their life histories, and the kinds of defenses their new hosts can muster. Once introduced, pests (which have relatively short life cycles) may undergo rapid evolutionary change in response to the new environment while their longer-lived tree hosts experience comparatively slower evolutionary change. Although several evolutionary factors may contribute to forest loss (Table 1), we focus here on phylogenetic similarity of floras and hybridization among pest species.

Most plants are resistant to most pathogens, even to those with which they have not coevolved, and phylogenetic relatedness is an effective predictor of the ability of pathogens (Gilbert and Webb 2007) and herbivores (Novotny et al. 2010) to cause infection. Thus, floras that are phylogenetically more similar to each other will be more vulnerable to the same groups of pests. Several hotspots of floristic similarity and potential vulnerability include the rainforests of Australia and Southeast Asia; the Gondwanan connections among the cooler regions of South America, New Zealand, and New Guinea; and the temperate forests of Europe, the northeastern US, and Southeast Asia.

Part of the vulnerability of phylogenetically related floras lies in the fact that although they experienced either paleohistorical connections or stepwise dispersal events, they have been separated long enough that independent coevolution with pathogens and insects has occurred. Therefore, physiological cues may still be present that elicit attack by the pests, but resistances may have diverged among related flora. For instance, Old World species of Viburnum have coevolved with Pyrrhalta viburni beetles, and have a wound response that expels the beetle's eggs. Viburnum species in North America lack this defense, however, and are succumbing to damage caused by $P$ viburni after its introduction to the New World (Desurmont et al. 2011). The Viburnum story is not an isolated one. Numerous damaging bark (subfamily Scolytinae) and ambrosia beetles (members of the weevil subfamilies Scolytinae and Platypodinae) are a threat to forests around the world (Hulcr and Dunn 2011). All of these have similarities to Viburnum beetle history: invasion of new ranges where the hosts are phylogenetically related but have over time evolved separately, such that feeding cue mismatches lead bark and ambrosia beetles to attack live instead of dead trees, as they do in their home range (Hulcr and Dunn 2011).

Pests can evolve quickly through hybridization (Brasier 2000), with changes in infectivity (the capacity to cause disease), aggressiveness (the amount of disease generated), and the ability to infect new hosts. Similar to the pattern described above for phylogenetically related plant species, related pests have been evolving divergently due to geographical separation. When brought into contact by humans, these organisms are often only incompletely reproductively isolated. An example of rapid change through hybridization is Dutch elm disease (DED) in Britain and northwest Europe (Brasier and Kirk 2010). Prior to 1900, DED was unknown in Europe and North America. The first pandemic was caused by the introduction of Ophiostoma ulmi from East Asia, peaking in about 1930 and leading to the death of $10-40 \%$ of elms in Europe. The second pandemic was caused by Ophiostoma novo-ulmi, also likely from East Asia, which peaked in the 1990s and led to the death of $>30$ million trees in the UK alone. O novo-ulmi is more aggressive than and outcompetes $\mathrm{O}$ ulmi, which it has steadily replaced in both Europe and North America (Brasier and Kirk 2010). The two species are anciently divergent and genetically distinct, but incompletely reproductively isolated; there are now extensive hybrid zones between the two species distributions across Europe, and these have acted as a bridge, enabling the flow of selectively favored genes from one species to the other (Paoletti et al. 2006). The 
resulting hybrids often have different host ranges than their progenitor species (Brasier 2000).

\section{Consequences for forests}

The long-term consequences of forest dieback as a result of non-native pests depend on many factors, including the density of host species in the environment, the average level and range of existing host resistance, the rate at which diseased trees die, and how unaffected tree species respond to the resources made available.

If the rate of mortality is relatively slow, then small forest gaps will be filled by other species. In the Appalachian Mountains of North America, for example, it took 30 years for chestnut blight ( $\mathrm{C}$ parasitica) to decrease the basal area of American chestnut (Castanea dentata) from $31 \%$ to less than $0.1 \%$. In the canopy, chestnuts were gradually replaced by other native species such as oak (Quercus spp) and maple (Acer spp; Day and Monk 1974). These forests are now less diverse, and all chestnut-dependent species have been reduced in abundance (Simberloff 2001). In general, forest loss will be more noticeable when common, dominant trees are attacked by a pest (which may or may not be a specialist) and in diverse forests where a generalist pest is able to attack host species from multiple genera or families. Although dieback of a single species within a diverse forest setting may not be obvious, the community of organisms dependent on that species will be adversely affected. Importantly, when forest structure is altered due to disease, a return to the previous forest type may not be possible even if the pathogen were to disappear, as other plant species will establish in the gaps left by the dying trees.

When dieback becomes obvious, there is an understandable desire to "do something" about it. In the early 1900s, many politicians were convinced that the spread of chestnut blight could be stopped, and control initiatives were attempted (Freinkel 2007). Unfortunately, once established, pest populations often subsequently expand rapidly, and, in combination with anthropogenic factors, tend to render attempts at control ineffective. The rate of spread may be slowed but is rarely halted. Strategies for longer-term forest restoration, such as breeding trees for resistance (Waring and Goodrich 2012) or biological control of the pest (Anagnostakis 1982), may offer opportunities for success. Nonetheless, the reality is challenging. Biocontrol involves the introduction of additional non-native species, with all of the attendant risks of such actions. Breeding trees for resistance is typically a long and arduous process, and it is difficult to replace extirpated forests with large-scale plantings of resistant trees in areas with complex patterns of land ownership. Despite considerable progress in chestnut breeding (Sniezko et al. 2012), for instance, there are still no examples of large-scale plantings of resistant trees. The situation is more promising in forests where the US
Government has large holdings. As a case in point, trees resistant to white pine blister rust are being planted in US National Forests ahead of the disease front (Schoettle et al. 2011; Waring and Goodrich 2012). All of these methods, which cannot replace the previous forest, are expensive, are retroactive, and would be unnecessary if relatively minor changes to policy were made.

\section{Conclusions and recommendations}

Given the common lag phase before incursions are recognized and the low probability of controlling pests once they have established, the management focus needs to be on preventing introductions in the first place, including targeted trade restrictions, penalties, and public education. In this section we lay out key recommendations.

Of particular concern is that the lax regulations pertaining to the movement of live plant materials need to be strengthened because there are now so many different ways by which this material is transported around the globe. "Instant" woody landscapes, in which large trees and shrubs (up to $10 \mathrm{~m}$ tall, with large root balls) are transported whole, have become increasingly popular (Brasier 2008). Cut flowers, which can include branches along with flowers and are commonly harvested from plants grown in commercial operations from Africa and South America, are shipped around the world (Dehnen-Schmutz et al. 2010). Crops and tree seedlings are often initially grown in one state or country and then shipped to another locality, where final growth occurs (Stapleton et al. 2001). In addition to tightening trade restrictions for live material, trade in the movement of plant products such as logs, wood chips, and wooden pallets must also be reduced (Aukema et al. 2011; Liebhold et al. 2012).

Existing regulations for imported plant material must be more proactive. Plant phytosanitary regulations vary by country but share the perspective - based on WTO rules - that until an organism is a genuine threat, no effort is made to restrict its transport or entry (Lodge et al. 2006; Brasier 2008). Regulation therefore tends to come into effect only after a problem is identified. Furthermore, only named species are put on lists of prohibited taxa (Brasier 2008), but many invading microorganisms are unknown to science, and so are not regulated until after damage has occurred and the causal organism has been named and described. The genus Phytophthora provides many examples (such as $P$ ramorum, $P$ alni, $P$ kernoviae, and $P$ pinifolia) of recent forest-killing invaders that were not known to science until after they were introduced to new areas (Brasier 2008). The worldwide Phytophthora scourge is probably not yet over, as an estimated 100-500 species remain to be discovered (Brasier 2008). A further problem is that the rates of processes associated with pest listing, naming, regulation, and control are much slower than those of international trade and new introductions. One reason why insects and pathogens are not always 
treated as "guilty until proven otherwise" is because this notion is unpopular with corporations, which fear greater associated financial costs. However, economic analyses that account for ecological losses over time indicate that the costs per citizen of invasions are high, providing financial incentives for governments to act (Keller et al. 2007; Burnett et al. 2012).

In addition to flawed international plant health regulations, problems with inspections and implementation of regulations need to be addressed. Plants-in-trade are accompanied by a phytosanitary certificate, issued by the exporting country, which indicates that the material is free from known noxious pests and diseases. At the port of entry, inspections of these materials are typically sporadic, visual only, and wholly inadequate. In the US, for example, billions of plants (usually containerized) are imported annually (Liebhold et al. 2012) but only about $2 \%$ are inspected (Brasier 2008). Even if a plant appears "healthy", pathogens and insects may be present (Denman et al. 2008). Pesticides and temperature treatments applied before shipping may suppress or delay pest development, but may not always kill the pest. Some newer and less toxic methods, such as "controlled atmosphere temperature treatment" (Follett and Neven 2006), show some promise for insects but are relatively untested for pathogens (Bautista-Banos et al. 2013), and are unlikely to be effective against internal pathogens. Furthermore, the treatment itself reduces plant quality (Follett and Neven 2006). Some will argue that free trade could continue if pest identification is improved by implementing molecular-based detection techniques. Nevertheless, this will work only with frequent inspections and with known pests. The vast majority of potential pests remain unknown to science; for instance, only about $7 \%$ of fungi have been scientifically described (Hawksworth 2004).

Many plant movements involve non-essential "luxury" materials that are primarily associated with the ornamental nursery trade. Distinguishing between plant materials that are essential for human health and welfare and concentrating phytosanitary measures and inspections on these alone should be a priority, with the luxuries imported only under license as small parcels of seedlings, seeds, or tissue cultures, subject to up to 2 years quarantine and, if deemed healthy, masspropagated locally (Brasier 2008). Trade in non-essential plant materials should be curtailed not only between countries but also between geographic regions of larger countries or trade zones; in the US, sudden oak death was dispersed from California to 1200 locations in 39 other states via infected camellias shipped from a wholesale nursery (Pautasso et al. 2010). Similarly, more than five million ash saplings, imported from other EU countries into the UK between 2003 and 2011 (Smith et al. 2013) were almost certainly involved in the spread of Chalara ash dieback from mainland Europe to the UK. Quarantine laws that could be used for this purpose already exist in the US (Filbey et al. 2002).

There must also be more substantial penalties levied against businesses (and potentially regulators) for introducing pests, both within countries and especially against exporting countries. Because the negative impacts of introduced forest pests appear long after the commercial transactions in pest-harboring plants have occurred, there are no financial incentives to discourage business practices that facilitate invasion. Since businesses have no incentive to self-correct, government regulation restrictions on shipping plants and plant products - is necessary for maintaining long-term economic and ecological viability.

Consumers could make informed decisions about buying plants and plant products if retail outlets were required to affix labels detailing geographic origin and production method (Brasier 2008). A green certification program could be established to label plants and plant products as "locally grown". All non-local phyto-certified plant products should be labeled with all countries and/or states through which they traveled.

The scientific community must better educate the public, politicians, trade organizations, foresters, horticulturalists, gardeners, and conservationists regarding the threats posed by non-native forest pests. Most people are unaware of increasing damage to forests from introduced pests; publicizing the environmental costs of these invasions and the occurrence of biosecurity breaches is important. The "Don't Move Firewood" educational campaign in the US is a step in the right direction. Marketing research conducted by The Nature Conservancy indicated that $80 \%$ of the US public was willing to change their behavior once they understood that moving firewood facilitates the spread of forest pests (L Greenwood pers comm).

Taking steps to ensure healthy forests may be one action that all nations can agree upon and that will have global benefits. The time to act is now. Although some consequences of pests are very dramatic and can be seen immediately, many others, such as white pine blister rust, may take years or even decades to develop and thus are hidden from a given generation's consciousness. This time delay could allow for the development of a shifting baseline - similar to that observed in fisheries (Pauly 1995) - in which forests become increasingly degraded, with the public largely unaware that it is happening.

\section{Acknowledgements}

This paper was inspired by The Fourth International Workshop on the Genetics of Host-Parasite Interactions in Forestry: Disease and Insect Resistance in Forest Trees, 31 Jul-5 Aug 2011, in Eugene, OR. Although all of us have studied plant-pathogen interactions for years, this workshop opened our eyes to the breadth and depth of the problems in forests. Thanks to J Stone for commenting on an early draft. 


\section{References}

ABRAF (Brazilian Association of Forest Plantation Producers). 2011. ABRAF statistical yearbook 2011: base year 2010. Brasilia, Brazil: ABRAF. http://research.cnr.ncsu.edu/sofac/ ABRAF_Statistical_Annual_Report_2011_English.pdf.

Anagnostakis SL. 1982. Biological control of chestnut blight. Science 215: 466-71.

Andjic V, Dell B, Barber P, et al. 2011. Plants for planting; indirect evidence for the movement of a serious forest pathogen, Teratosphaeria destructans, in Asia. Eur J Plant Pathol 131: 49-58.

Aukema JE, Leung B, Kovaks K, et al. 2011. Economic impacts of non-native forest insects in the continental United States. PLoS ONE 6: e24587.

Aukema JE, McCullough DG, Von Holle B, et al. 2010. Historical accumulation of nonindigenous forest pests in the continental United States. BioScience 60: 886-97.

Bautista-Banos S, Sivakumar D, Bello-Perez A, et al. 2013. A review of the management alternatives for controlling fungi on papaya fruit during the postharvest supply chain. Crop Prot 49: $8-20$.

Brasier CM. 2000. Rise of the hybrid fungi. Nature 405: 134-35.

Brasier CM. 2008. The biosecurity threat to the UK and global environment from international trade in plants. Plant Pathol 57: 792-808.

Brasier CM and Kirk SA. 2010. Rapid emergence of hybrids between the two subspecies of Ophiostoma novo-ulmi with a high level of pathogenic fitness. Plant Pathol 59: 186-99.

Brasier C and Webber J. 2010. Plant pathology: sudden larch death. Nature 466: 824-25.

Burdon JJ and Chilvers GA. 1982. Host density as a factor in plant disease ecology. Annu Rev Phytopathol 20: 143-66.

Burgess T and Wingfield MJ. 2001. Exotic pine forestry in the Southern Hemisphere: a brief history of establishment and quarantine practices. S Afr Forest J 192: 79-83.

Burnett K, D'Evelyn S, Loope L, and Wada CA. 2012. An economic approach to assessing import policies designed to prevent the arrival of invasive species: the case of Puccinia psidii in Hawai'i. Environ Sci Pol 19-20: 158-68.

Carnegie AJ and Cooper K. 2011. Emergency response to the incursion of an exotic myrtaceous rust in Australia. Australas Plant Path 40: 346-59.

Costanza R, D'Arge R, De Groot R, et al. 1997. The value of the world's ecosystem services and natural capital. Nature 387: 253-60.

Day FP and Monk CD. 1974. Vegetation patterns on a Southern Appalachian watershed. Ecology 55: 1064-74.

Dehnen-Schmutz K, Holdenrieder O, Jeger MJ, and Pautasso M. 2010. Structural change in the international horticultural industry: some implications for plant health. Sci HorticAmsterdam 125: 1-15.

Denman S, Moralejo E, Kirk SA, et al. 2008. Sporulation of Phytophthora ramorum and $P$ kernoviae on asymptomatic foliage. Proceedings of the Sudden Oak Death Third Science Symposium; 5-9 Mar 2007; Santa Rosa, CA. Albany, CA: US Department of Agriculture, Forest Service, Pacific Southwest Research Station.

Desurmont GA, Donoghue MJ, Clement WL, and Agrawal AA. 2011. Evolutionary history predicts plant defense against an invasive pest. P Natl Acad Sci USA 108: 7070-74.

Dietz $\mathrm{H}$ and Edwards PJ. 2006. Recognition that causal processes change during plant invasion helps explain conflicts in evidence. Ecology 87: 1359-67.

Evans EA, Crane J, Hodges A, and Osborne JL. 2010. Potential economic impact of laurel wilt disease on the Florida avocado industry. Horttechnology 20: 234-38.

FAO (UN Food and Agriculture Organization). 2009a. Global review of forest pests and diseases. Rome, Italy: FAO. FAO Forestry Paper 156.
FAO (UN Food and Agriculture Organization). 2009b. State of the world's forests 2009. Rome, Italy: FAO.

Filbey M, Kennedy C, Wilkinson J, and Balch J. 2002. Halting the invasion: state tools for invasive species management. Washington, DC: Environmental Law Institute.

Fisher MC, Henk DA, Briggs CJ, et al. 2012. Emerging fungal threats to animal, plant and ecosystem health. Nature 484: 186-94.

Follett PA and Neven LG. 2006. Current trends in quarantine entomology. Annu Rev Entomol 51: 359-85.

Fraedrich SW, Harrington TC, Rabaglia RJ, et al. 2008. A fungal symbiont of the redbay ambrosia beetle causes a lethal wilt in redbay and other Lauraceae in the southeastern United States. Plant Dis 92: 215-24.

Freinkel S. 2007. American chestnut: the life, death, and rebirth of a perfect tree. Berkeley, CA: University of California Press.

Gilbert GS and Webb CO. 2007. Phylogenetic signal in plant pathogen-host range. P Natl Acad Sci USA 104: 4979-83.

Goss EM, Larsen M, Vercauteren A, et al. 2011. Phytophthora ramorum in Canada: evidence for migration within North America and from Europe. Phytopathology 101: 166-71.

Haack RA. 2006. Exotic bark- and wood-boring Coleoptera in the United States: recent establishments and interceptions. Can J Forest Res 36: 269-88.

Hawksworth DL. 2004. Fungal diversity and its implications for genetic resource collections. Stud Mycol 50: 9-18.

Hulcr J and Dunn RR. 2011. The sudden emergence of pathogenicity in insect-fungus symbioses threatens naive forest ecosystems. Proc Roy Soc B 278: 2866-73.

Keane RE, Tomback DF, Aubry CA, et al. 2012. A range-wide restoration strategy for whitebark pine (Pinus albicaulis). Fort Collins, CO: US Department of Agriculture, Forest Service, Rocky Mountain Research Station. General Technical Report RMRS-GTR-279.

Keller RP, Lodge DM, and Finnoff DC. 2007. Risk assessment for invasive species produces net bioeconomic benefits. P Natl Acad Sci USA 104: 203-07.

Kluza DA, Vieglais DA, Andreasen JK, and Peterson AT. 2007. Sudden oak death: geographic risk estimates and predictions of origins. Plant Pathol 56: 580-87.

Liebhold AM, Brockerhoff EG, Garrett LJ, et al. 2012. Live plant imports: the major pathway for forest insect and pathogen invasions of the US. Front Ecol Environ 10: 135-43.

Lodge DM, Williams S, MacIsaac HJ, et al. 2006. Biological invasions: recommendations for US policy and management. Ecol Appl 16: 2035-54.

Mayfield III AE and Thomas MC. 2009. Pest alert: the redbay ambrosia beetle, Xyleborus glabratus Eichhoff (Scolytinae: Curculionidae). Gainesville, FL: Division of Plant Industry, Florida Department of Agriculture and Consumer Services. DACS-P-01651.

Mitchell CE, Tilman D, and Groth JV. 2002. Effects of grassland plant species diversity, abundance, and composition on foliar fungal disease. Ecology 83: 1713-26.

Novotny V, Miller SE, Baje L, et al. 2010. Guild-specific patterns of species richness and host specialization in plant-herbivore food webs from a tropical forest. J Anim Ecol 79: 1193-203.

Oliveira AT and Fontes MAL. 2000. Patterns of floristic differentiation among Atlantic forests in southeastern Brazil and the influence of climate. Biotropica 32: 793-810.

Paoletti M, Buck KW, and Brasier CM. 2006. Selective acquisition of novel mating type and vegetative incompatibility genes via interspecies gene transfer in the globally invading eukaryote Ophiostoma novo-ulmi. Molec Ecol 15: 249-63.

Pauly D. 1995. Anecdotes and shifting baseline syndrome of fisheries. Trends Ecol Evol 10: 430.

Pautasso M, Aas G, Queloz V, and Holdenrieder O. 2013. European ash (Fraxinus excelsior) dieback - a conservation biology challenge. Biol Conserv 158: 37-49. 
Pautasso M, Dehnen-Schmutz K, Holdenrider O, et al. 2010. Plant health and global change - some implications for landscape management. Biol Rev 85: 729-55.

Peña JE, Carrillo D, Duncan R, et al. 2012. Susceptibility of Persea spp and other Lauraceae to attack by redbay ambrosia beetle, Xyleborus glabratus (Coleoptera: Curculionidae: Scolytinae). Fla Entomol 95: 783-87.

Pérez CA, Wingfield MJ, Altier N, and Blanchette RA. 2013. Species of Mycosphaerellaceae and Teratosphaeriaceae on native Myrtaceae in Uruguay: evidence of fungal host jumps. Fungal Biol 117: 94-102.

Pérez CA, Wingfield MJ, Slippers B, et al. 2008. Diseases of introduced Eucalyptus and native Myrtaceae in Uruguay: new cases of host jumping. APS National Meeting; 26-30 Jul 2008; St Paul, MN. Phytopathology 98: S124.

Perry DA, Orem R, and Hart SC. 2008. Forest ecosystems (2nd edn). Baltimore, MD: Johns Hopkins University Press.

Rizzo DM, Garbelotto M, Davidson JM, et al. 2002. Phytophthora ramorum as the cause of extensive mortality of Quercus spp and Lithocarpus densiflorus in California. Plant Dis 86: 205-14.

Roy BA, Coulson T, Blaser W, et al. 2011. Population regulation by enemies of the grass Brachypodium sylvaticum: demography in native and invaded ranges. Ecology 92: 665-75.

Sakalidis ML, Slippers B, Wingfield BD, et al. 2013. The challenge of understanding the origin, pathways and extent of fungal invasions: global populations of the Neofusicoccum parvum-N ribis species complex. Divers Distrib 19: 873-83.

Santini A, Ghelardini L, De Pace C, et al. 2013. Biogeographical patterns and determinants of invasion by forest pathogens in Europe. New Phytol 197: 238-50.

Schoettle AW, Goodrich BA, Klutsch JG, et al. 2011. The proactive strategy for sustaining five-needle pine populations: an example of its implementation in the southern Rocky Mountains. Proceedings of the High Five Symposium; 28-30
Jun 2010; Missoula, MT. Fort Collins, CO: US Department of Agriculture, Forest Service, Rocky Mountain Research Station.

Simberloff D. 2001. Biological invasions - how are they affecting us, and what can we do about them? West N Am Naturalist 61: 308-15.

Smith C, Johnson A, Fernall D, et al. 2013. Chalara in ash trees: a framework for assessing ecosystem impacts and appraising options. United Kingdom: Department for Environment, Food and Rural Affairs.

Sniezko RA, Yanchuk AD, Kleijunas JT, et al. 2012. Proceedings of the Fourth International Workshop on the Genetics of Host-Parasite Interactions in Forestry: Disease and Insect Resistance in Forest Trees. Albany, CA: Pacific Southwest Research Station, US Department of Agriculture. General Technical Report PSW-GTR-240.

Stapleton SC, Chandler CK, Legard DE, et al. 2001. Transplant source affects fruiting performance and pests of "Sweet Charlie" strawberry in Florida. Horttechnology 11: 61-65.

Vehvilainen H, Koricheva J, and Ruohomaki K. 2007. Tree species diversity influences herbivore abundance and damage: metaanalysis of long-term forest experiments. Oecologia 152: 287-98.

Waring KM and Goodrich BA. 2012. Artificial regeneration of five-needle pines of western North America: a survey of current practices and future needs. Tree Planters' Notes 55: 55-71.

Wingfield MJ, Slippers B, Roux J, and Wingfield BD. 2001. Worldwide movement of exotic forest fungi, especially in the tropics and the Southern Hemisphere. BioScience 51: 134-40.

Xu H, Qiang S, Han Z, et al. 2006. The status and causes of alien species invasion in China. Biodivers Conserv 15: 2893-904.

Zauza EAV, Alfenas AC, Old K, et al. 2010. Myrtaceae species resistance to rust caused by Puccinia psidii. Australas Plant Path 39: $406-11$.

\section{Assistant Professor EES}

\section{Furman University}

Job Description Summary:

The Department of Earth and Environmental Sciences at Furman University, a private liberal arts undergraduate institution, invites applications for a tenure-track position at the Assistant Professor level beginning in August 2015. A PhD is required at the time of appointment.

The ideal candidate will have a background in Sustainability Science or a related field with a sustainability science focus. Applicants should have demonstrated teaching and research expertise focusing on the interactions and feedbacks between environmental and social or human systems related to problems of sustainability. Teaching responsibilities consist of four courses with labs per year, including SUS 120 Principles of Sustainability Science and SUS 241 Social Systems, with the potential opportunity to teach upper level courses in the candidate's specialty.

In addition to teaching, the successful candidate will develop an active undergraduate research program and interact closely with the Shi Center for Sustainability.

\section{Minimum Qualifications:}

- $\mathrm{PhD}$ is required at the time of appointment.

- Background in Sustainability Science or a related field with a sustainability science focus.

- Demonstrated teaching and research expertise focusing on the interactions and feedbacks between environmental and social or human systems related to problems of sustainability.

- Develop an active undergraduate research program and interact closely with the Shi Center for Sustainability.

\section{Close Date: 12/01/2014}

To be considered for this position, please visit our web site and apply online at the following link:

\section{http://apptrkr.com/519701}

Furman University is an equal opportunity employer strongly committed to diversity within its community.

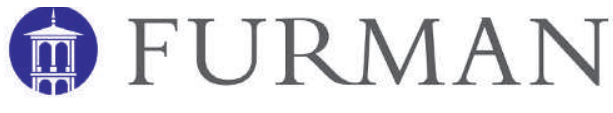

